\title{
Bacterial Pathogen Responsible For Urinary Tract Infection.
}

\author{
Raina Chaudhary ${ }^{1}$, Chet Raj Ojha ${ }^{1}$, Khagendra Sijapati ${ }^{1}$, Sunil Kumar Singh ${ }^{1}$.
}

${ }^{1}$ Microbiologist, Department of Pathology, Shree Birendra Hospital.

\begin{abstract}
Introduction: Urinary Tract Infection (UTI) is one of the common medical conditions which seek the help of clinician and prompt intervention with suitable antibiotics to prevent morbid conditions. Therefore, identification of causative agent with their antibiotic sensitivity pattern is always mandatory for successful treatment of the cases.
\end{abstract}

The main objective of the study was to identify the common bacterial pathogen responsible for causing Urinary Tract Infection with determination of sensitivity pattern of commonly used antibiotics.

Methods: A total of 8270 urine samples were collected from the patient attending Outpatient Department and admitted as Inpatient in ward during the period of January 2011 to December 2011 in Shree Birendra Hospital. The samples were subjected to culture for identification of pathogen with their antibiotic sensitivity pattern following standard methodology.

Results: Out of total, only1654 (20\%) showed growth of pathogenic organisms. Among them positivity was highest in patient attending Outpatient Department. Eight different species of bacteria was isolated as causative agent. Among them Escherichia coli (67\%) was predominantly higher in number followed by Proteus spp (22.24\%), Klebsiellaspp (4.07\%), Pseudomonas aeruginosa(2.7\%) and Citriobacterfreundii (2.3\%). Among these organisms sensitivity was highest towards Amikacin (86\%) \& Gentamycin (69\%) followed by Nitrofurantion (60.5\%).

Conclusions: Causative agent of Urinary Tract Infection may vary in different situation. Definite identification of pathogen with their antibiotic sensitivity pattern is always key point for success of treatment.

Keywords: antibiotic sensitivity, E. coli, UTI

\section{INTRODUCTION}

Urinary tract infections (UTI) could be defined as the persistent presence of actively multiplying microorganisms within the urinary tract. UTI implies both microbial colonization of the urine and invasion of the lower or upper urinary tract by microorganisms ${ }^{1}$. According to Kass ${ }^{2}$ presence of 100000 or more colony forming units (CFU) of bacteria per $\mathrm{ml}$ of urine implies UTI. But this criteria has been questioned and bacterial counts of $10^{2}$ or more organism per $\mathrm{ml}$ particularly when accompanied by pyuria
(>10 $\mathrm{wbc} / \mathrm{mm}^{3}$ ) provide impressive evidence of urinary tract infection in symptomatic young women ${ }^{3}$.Therefore, the Infectious Disease Society of America (IDSA) gave a slightly more relaxed consensus definition requiring $10^{3}$ organisms per $\mathrm{ml}$ to diagnose cystitis and $10^{4}$ per $\mathrm{ml}$ for pyelonephritis ${ }^{4}$.

It is among the most common bacterial infections encountered by clinicians in developing countries with an estimated annual global incidence of at least 250 million. It has been estimated that symptomatic UTIs result in

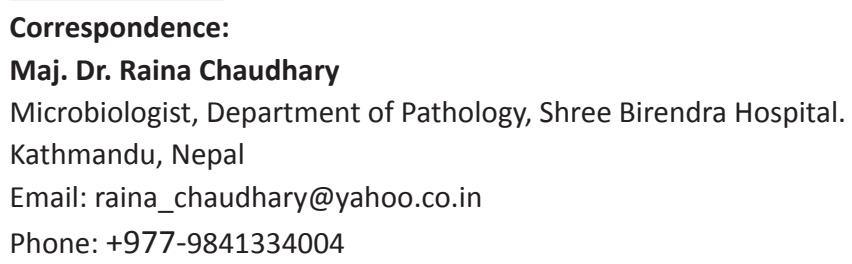


as many as 7 million visits to outpatient's clinics and 1 million visits to emergency department and 100,000 hospitalizations annually ${ }^{5}$.

UTIs have become the most common hospital-acquired infection, accounting for as many as $35 \%$ of nosocomial infections and they are the second most common cause of bacteremia in hospitalized patients ${ }^{6}$. But fortunately it is rapidly responsive to modern antibiotic therapy.

Therefore, study of the causative agent with their antibiotic sensitivity pattern is necessary tools for treatment and it also gives guideline for empirical therapy where there is laboratory facilities lacking. With all these views the present study was carried out to know the common bacterial isolates involve in Urinary Tract Infection among the patients attending Shree Birendra Hospital, Chauni with their sensitivity pattern.

\section{METHODS}

This study was conducted retrospectively from January 2011 to December 2011.Clinically suspected cases of Urinary Tract Infection were included in this study. Of total 8270 urine samples were collected during the period. All the samples were processed according to standard methodology guided by CLSI (Clinical Laboratory Standard Institute) $)^{7-8}$ and antibiotic sensitivity pattern were determined by Modified Kirby's Bauer method ${ }^{9}$.

\section{RESULTS}

Among 8270 urine sample processed, only 1654 showed significant growth. It constitutes $20 \%$ of positivity as shown in the figure 1.
During the study E.coli(67.2\%) was found to be the predominant organism followed by Proteus spp (22.2\%), Klebsiellaspp (4.05\%) and P.aeruginosa $(2.78 \%)$ as shown in Table 1.

In the study isolated organisms showed sensitivity towards Aminoglycoside group of antibiotics like Amikacin (86\%) and Gentamycin (69\%) followed by Nitrofurantion (60.5\%). Table 2 showing the elaborated sensitivity pattern of each of isolate.

Figure 1. Pattern of Growth positivity $(n=8270)$

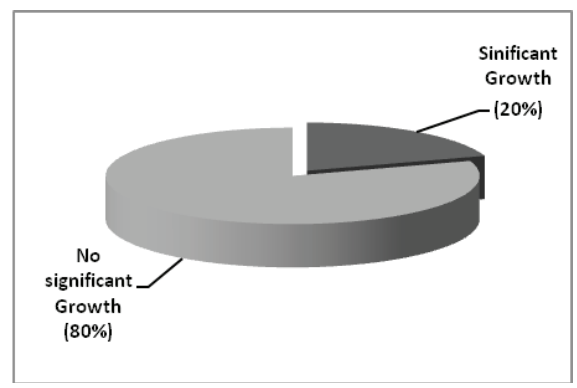

Table 1. Pattern of Bacterial Isolates $(n=1654)$

\begin{tabular}{|lll|}
\hline Organisms & Total Numbers & \% \\
\hline Escherichia coli & 1111 & 67.2 \\
\hline Proteus spp & 366 & 22.12 \\
\hline Klebsiellaspp & 67 & 4.05 \\
\hline Pseudomonas aeruginosa & 46 & 2.78 \\
\hline Citrobacterfreundii & 38 & 2.29 \\
\hline Morganellamorganii & 18 & 1.08 \\
\hline Providenciaspp & 6 & 0.36 \\
\hline Acinetobacterspp & 2 & 0.12 \\
\hline
\end{tabular}

Table 2. Sensitivity Pattern for different Antibiotic.

\begin{tabular}{|l|l|l|l|l|l|l|l|l|}
\hline Antibiotics & $\begin{array}{l}\text { E.coli } \\
\mathbf{n = 1 1 1 1}\end{array}$ & $\begin{array}{l}\text { Proteus } \\
\text { spp } \\
\mathbf{n = 3 6 6}\end{array}$ & $\begin{array}{l}\text { Klebsiellaspp } \\
\mathbf{n = 6 7}\end{array}$ & $\begin{array}{l}\text { P.aeruginosa } \\
\mathbf{n = 4 6}\end{array}$ & $\begin{array}{l}\text { C.freundii } \\
\mathbf{n = 3 8}\end{array}$ & $\begin{array}{l}\text { M.morganii } \\
\mathbf{n = 1 8}\end{array}$ & $\begin{array}{l}\text { Providenciaspp } \\
\mathbf{n = 6}\end{array}$ & $\begin{array}{l}\text { Acinetobacterspp } \\
\mathbf{n = 2}\end{array}$ \\
\hline Amoxicillin & 118 & 73 & ND & ND & 14 & 5 & 1 & 0 \\
\hline Amikacin & 920 & 343 & 65 & 42 & 32 & 15 & 6 & 1 \\
\hline Cephalexin & 119 & 125 & 15 & ND & 10 & 3 & 1 & 0 \\
\hline Ceftazidime & ND & ND & ND & 37 & ND & ND & ND & 1 \\
\hline Co-trimoxazole & 355 & 112 & 20 & ND & 13 & 12 & 4 & 2 \\
\hline Cefotaxime & 187 & 250 & 7 & ND & 30 & 12 & 6 & 1 \\
\hline Gentamycin & 816 & 250 & 43 & ND & 24 & 16 & 4 & 0 \\
\hline Norfloxacin & 344 & 141 & 29 & 22 & 19 & 8 & 5 & 0 \\
\hline Nitrofurantoin & 716 & 184 & 18 & 41 & 20 & 17 & 6 & 0 \\
\hline Ofloxacin & 409 & 193 & 34 & 30 & 18 & 16 & 6 & 2 \\
\hline Piperacillin & ND & ND & ND & 35 & ND & ND & ND & ND \\
\hline
\end{tabular}

ND-Not Done 


\section{DISCUSSION}

Bacterial infection of the urinary tract is one of the common causes for seeking medical attention in the community. Effective management of patients suffering from bacterial UTIs commonly relays on the identification of causative organism and the selection of proper antibiotic.

Escherichia coli is the most frequently isolated bacteria in both community acquired as well as hospitalized patients 10-12 Therefore, this study is also no more exception and isolated E.coli (67.2\%) as predominant organism. This was followed by Proteusspp (22.12\%) and Klebsiellaspp(4.05\%). Various studies showed Enterococcus fecalis ${ }^{13}$, Klebsiella pnumoniae $^{14,15}$, Staphylococcus aureus ${ }^{16,17}$ as second commonest organisms. But this study was contrary to other studies. Most interestingly during this study Proteus spp was found to be the second commonest organism. The reasons behind this may be the isolates were from the patients admitted in the hospital.

However, the study was unable to focus on other bacterial causes like Neisseria gonorrhoeae, Chlamydia trachomatis, Mycoplasmagenitalium.

According to this study E.colishowed effective sensitivity towards Amikacin (82.8\%), Gentamycin (73.44\%) and Nitrofurantion (64.4\%). This result was similar to the study done by H.P. Kattel ${ }^{16}$ Amikacin (81.5\%), Getamycin(65\%) and Nitrfurantion(79.2\%), A Acharya ${ }^{18}$; Amikacin (77.92\%), Gentamycin (73.1\%) and Nitrofurantion (71.2\%) from Nepal. But the study showed commonly used antibiotic like Amoxicillin (89.4\%) as highest resistance, the result was similar with the study result by A. Acharya ${ }^{18}(100 \%)$ from Nepal, Asad U Khan ${ }^{19}$ (90\%) from India, Ava Behrooozi ${ }^{20}(85 \%)$ from Iran, Savitha $\mathrm{T}^{21}$ (69.39\%) from India and Annabelle T. Dytan ${ }^{22}$ (55.6\%) from Philippine. Therefore, there is no doubt the commonest causative organism of UTI is no longer responsive to commonly prescribed antibiotic.

Other Gram negative bacteria are also showing the similar type of sensitivity pattern. So we can conclude that Amikacin and Gentamycin is the drug of choice for the Gram negative bacilli as uropathgen for UTI. But its drawback is that need to be administered intravenously and might need hospital admission. Therefore, Nitrofurantion can be taken as best option for first line drug and it is readily available in affordable price in developing countries like Nepal. It is found to be safe even in pregnancy ${ }^{23}$. Even than clinicians are so reluctant to prescribe such wonderful drug.

But Pseudomonas aeruginosa was showing different type of sensitivity pattern. This organism was isolated from admitted patient and accounted for only $2.78 \%$ of total which was in accordance with the study result done by A Acharya ${ }^{18}$ et.al (2.9\%), A Sharma ${ }^{14}$ et.al (2.5\%) from Nepal. Pseudomonas aeruginosashowed sensitivity towards Amikacin (91\%), Nitrofurantaion (89.1\%) and Ceftazidime (80.43\%). The sensitivity pattern of Amikacin and Nitrofurantaion is similar with study done by $A$ Behrooozi ${ }^{20}$ et.al ;Amikacin (87\%) and Nitrofurantion (74\%).

The study showed that treatment option is being narrowed down due to emergence of multi drug resistance organisms. Therefore, the mechanism of resistance pattern has to be studied in detail in near future with best alternative choice of drug.

\section{CONCLUSIONS}

Constant survey of antimicrobial sensitivity pattern plays a very important role in the empiric treatment of UTIs. In health care setting, a very little extra venture on antimicrobial sensitivity pattern survey can facilitate to accrue extremely practical information of resistance pattern as well as successful treatment.

\section{ACKNOWLEDGEMENT}

Author is grateful to all the laboratory staffs members of Microbiology Unit, Department of Pathology, Shree Birendra Hospital for their generous support for conducting this study.

\section{REFERENCES}

1. Reid G, Sobel JD. Bacterial adherence in the pathogenesis of urinary tract infection: a review. Rev Infect Dis. 1987;9:470-87.

2. Kass EH. Asymptomatic infections of the urinary tract. Trans Assoc Am Physicians. 1956;69:56-64.

3. Stamm WE, Counts GW, Running KR, Fihn S, Turck M, Holmes KK. Diagnosis of coliform infection in acutely dysuria women. N Engl J Med. 1982;307:463-8.

4. Hooton TM, Stamm WE. Diagnosis and treatment of uncomplicated urinary tract infection. Infect Dis Clin North Am. 1997;11:551-81.

5. Schappert SM.Ambulatory care visits to physician offices, hospital outpatient departments, and emergency departments: United States,1997. Vital Health Stat 13. 1999;143:1-39.

6. Stamm WE. Scientificand clinical challenges in the management of urinary tract infections. Am J Med. 2002;113:1-4. 
7. Collee JG, Duguid JP, Fraser AG, Marmmion $\mathrm{BP}$, Simmons A. Laboratory strategy in the diagnosis of infective syndromes. In: Mackie and McCartney, Practical Medical Microbiology. $14^{\text {th }}$ ed, London. Churchill Livingstone 1996: pp84-90.

8. Betty AF, Daniel FS, Alice SW. Overview of bacterial identification and strategies. In: Bailey and Scott's Diagnostic Microbiology. $12^{\text {th }}$ ed, Philadelphia. Mosby. 2007: pp216-47.

9. Matthew AW, Franklin RC, William AC, Michael ND, George ME, David WH, et al. Performance standards for antimicrobial disc susceptibility test, Approved standard in Clinical and Laboratory Standards Institute (CLSI). M2-A9. $9^{\text {th }}$ ed, Pennsylvania Wayne, 2006; pp26.

10. Gruneberg RN. Changes in urinary pathogens and their antibiotic sensitivities. J Antimicrob Chemother.1994;33 1-8.

11. MacGowan AP, Brown NM, Holt HA, Lovering AM, McCulloch SY, Reeves DS. An eight-year survey of the antimicrobial susceptibility patterns of 85,971 bacteria isolated from patients in a district general hospital and the local community. J Antimicrobchemother. 1993;31:543-57.

12. Barrett SP, Savage MA, Rebec MP, Guyot A, Andrews N,Shrimpton SB.Antibiotic sensitivity of bacteria associated with community-acquired urinary tract infection in Britain.

J AntimicrobChemother.1999;44:359-65.

13. T Shilpi, SMA Huq, M Khatun. Pattern of Bacteria Causing Urinary Tract Infection of inpatient and outpatient department of Anwer Khan Modern Medical College Hospital. AKMMCJ. 2012;3(1):13-5.

14. Sharma A, Shrestha S, Upadhya S and Rijal P. Clinical and Bacteriological profile of urinary tract infection in children at Nepal Medical College Teaching Hospital. Nep Med Coll J. 2011;13 (1):24-6.
15. Manjunath GN, Prakash R, Vamseedhar Annam, KiranShetty. Changing trends in the spectrum of antimicrobial drug resistance pattern of uropathogens isolated from hospitals and community patients with urinary tract infections in Tumkur and Banglore. Int. J Biol Med Res 2011;2 (2):504-7.

16. Kattel HP, Acharya J, Mishra SK, Rijal BP, Pokharel BM. Bacteriology of Urinary Tract Infection Among Patients Attending Tribhuvan University Teaching Hospital, Kathmandu, Nepal. JNAMLS 2008;9 (1):25-9.

17. Okonko IO, ljandipe LA, Ilusanya OA et al. Incidence of urinary tract infection (UTI) among pregnant women in Ibadan, South -Western Nigeria. Afr J Biotechnol2009;8(23);6649-57.

18. Acharya A, Gautam R, Subedee L. Uropathogens and their antimicrobial susceptibility pattern in Bharatpur, Nepal. Nepal Med Coll J 2011;13 (1):30-3.

19. Ashad U Khan, Mohd S Zaman. Multiple drug resistance patterns in Urinary Tract Infection patients in Alighar. Biomed. Rech 2006;17 (3):179-81.

20. Behrooozi A, Rahbar M, Yousefi JV. A survey on epidemiology of urinary tract infections and resistance pattern of uropathogens in an Iranian1000-bed tertiary carehospital.Afr J Micro Res 2010;4(9):753-6.

21. Savitha T, Murugan K, Thangamariappan K. Prevalence Study on Emergence of Urinary Tract Infection in Erode, Tamil Nadu, India. Int. J Curt Res 2011;2(1):67-72.

22. Annabelle T. Dytan JA. Chua. Surveillance of Pathogens and Resistance Patterns in Urinary Tract Infections.Phil J Microbiol Infect Dis 1999;28(1):11-4.

23. Delzell JE Jr et al. Urinary tract infection during pregnancy. Am FamPhy 2000;61:712. 